\title{
CURRENT TRENDS OF PROTECTIONISM IN SHIPPING INDUSTRY (2015-2018)
}

\author{
Zhykharieva V. V., Shyriaieva L. V., Vlasenko O. S.
}

\section{INTRODUCTION}

The shipping industry serving foreign trade has a strategic importance for economy, in recent years it occupied more than $80 \%$ in the world on volume of transportation and more than $70 \%$ at cost ${ }^{1}$. High capital value of vessels and volatility of freight rates lead to financial difficulties for the ship owners during periods of low conjuncture of the freight markets. During the different historical periods the developed and developing countries used various methods of the state protectionism in shipping industry. Taking into account the changes of approaches to the state protectionism, features and volumes of their application in different countries, emergence of new measures, studying the current tendencies of protectionism in shipping, detection of pros and cons of their application, improvement of classification of protectionist methods in shipping industry are important and actual.

Most of authors researched protectionist measures in the sphere of trade and their influence on shipping industry. The protectionist measures were used in the 1980s and their influence on the international shipping are considered in the book by A. Odeke ${ }^{2}$. The tendency of trade and services liberalization in 1970-1980s on the basis of the General Agreement on Tariffs and Trade (GATT) and the main directions of use of the indirect protectionist measures by the developed European countries are considered in the article by G. N. Yannopoulos ${ }^{3}$. The barriers to trade in maritime transport services and regulatory framework of the World Trade Organisation (WTO) and the General Agreement on trade in services (GATS) were researched in the paper of B. Parameswaran ${ }^{4}$.

${ }^{1}$ Odeke A. (1984) Protectionism and the Future of International Shipping. Dordrecht: Martinus Nijhoff Publishers.

${ }^{2}$ Yannopoulos G. N. (1989) World Shipping: Between Liberalism and Protectionism. North Carolina Journal of International Low and Commercial Regulation, vol. 14, no. 1, pp. 45-53.

${ }^{3}$ Parameswaran B. (2004) The liberalization of Maritime Transport Services. Berlin: Springer-Verlag Berlin and Heidelberg GmbH \& Co. KG.

${ }^{4}$ Kirk A. (2017) Protectionism is on the rise as US and EU implement thousands of restrictive trade measures. The Telegraph (electronic journal), 28 November 2017. URL: https://www.telegraph.co.uk/business/2017/11/28/mapped-protectionism-rise-us-euimplement-thousands-restrictive/ (accessed 2 November 2018). 
In the article by $\mathrm{A}$. Kirk ${ }^{5}$ a growth of use of the protectionist measures in the trade by the different countries after financial crisis of 2008-2009 is considered. It is specified that 60 countries use more than 7000 measures directed to protection of foreign trade. Significant amount of the protectionist measures is used by United States, India, Argentina, Russian Federation, Japan, the United Kingdom, Germany, Italy, France and Poland.

Shipping companies of the EU faced growth of protectionism in many parts of the world; at the same time the foreign shipping policy of the EU has to be aimed at the development of the global open markets and providing equal conditions of access to sea transport services ${ }^{6}$.

The research aims on systematization of practical experience of state protectionism in shipping industry at the current stage of its development, improvement of the classification of protectionist measures in shipping, allocation of the main trends of the state protectionism in shipping, the analysis of reasons, advantages and disadvantages of the state protectionism in maritime industry from macroeconomic and microeconomic points of view.

The methodological basis of the research is: system approach, economic regularities, general provisions of maritime economics, the principles of shipping management, scientific works of the leading scientists and experts in maritime economics. During the research scientific theoretical and empirical methods were used: analysis and synthesis of results and retrospective, logic and analytical methods, method of statistical information processing.

\section{PRECONDITIONS FOR APPLICATION OF PROTECTIONIST MEASURES IN SHIPPING INDUSTRY}

Broad application of protectionist measures in the world shipping industry is connected with the aspiration of governments to develop national fleets, to ensure economic security, as well as with using by ship owners of "flags of convenience" at registration of vessels in offshore jurisdictions and the low level of profitability of the shipping business connected with a high shipbuilding value and capital costs, very high level of competition and volatility on the international freight markets. This statement is confirmed by the following statistical data.

In 2017 more than $70 \%$ of the tonnage of the world commercial fleet was registered under the flags, that differed from flags of the fleet ownership countries. The rating of 20 countries, which were the largest ship owners in 2016-2017, the growth rates of the general deadweight and the tonnage registered under foreign flags, are presented in tab. 1.

5 European Community Shipowners' Association (2017) Shipping and global trade. Toward to EU external shipping policy, Brussels: ECSA.

${ }^{6}$ Zhykharieva V., Shyriaieva L., Vlasenko O. (2019) Current trends of protectionism in shipping industry. Transport Problems, vol. 14, issue 2, pp. 89-100. DOI: $10.20858 /$ tp.2019.14.2.8 
Apparently from the submitted data, the majority of the countries have a significant share of the tonnage under foreign flags. The greatest growth rate of this indicator in the analysed period is shown by the Russian Federation, Singapore and Switzerland. Besides in the majority of the countries the growth rate of the deadweight tonnage under foreign flags exceeds growth rate of the total tonnage.

Growth rates of the fleet by flags registration are presented in tab. 2. In this rating such typical offshore jurisdictions as Panama, Liberia and the Marshall Islands are in the lead, and the tonnage of the registered fleet continued to grow in 2016-2017. The significant tonnage is registered under the flags of traditional maritime nations - China, Greece, the United Kingdom, Japan and Norway.

The financial results of the three global container carriers in 2016-2017 are shown in tab. 3. In 2017 A.P Moller - Maersk took the first place among container operators, CMA CGM - the third place and Hapag-Lloyd - the fifth place. The data demonstrate the low level of EBITDA margin on the considered companies, which did not exceed $11.4 \%$ in 2016-2017, besides these companies, and their losses and profits significantly fluctuate by years.

Table 1

Top 20 countries and territories by world fleet ownership 2016

2017

\begin{tabular}{|c|c|c|c|c|c|c|c|c|}
\hline \multirow{3}{*}{ 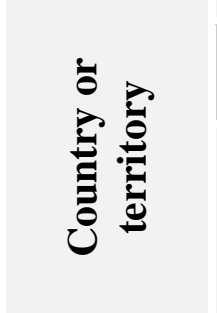 } & & & & & & & \multirow{3}{*}{ 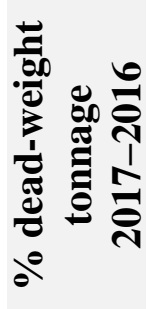 } & \multirow{3}{*}{ 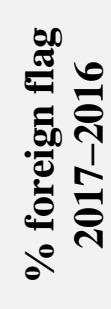 } \\
\hline & \multicolumn{2}{|c|}{$\begin{array}{l}\text { thousands of } \\
\text { deadweight tons }\end{array}$} & \multirow{2}{*}{ 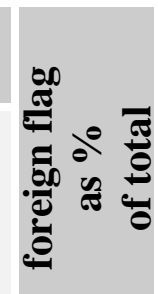 } & \multicolumn{2}{|c|}{$\begin{array}{l}\text { thousands of } \\
\text { deadweight tons }\end{array}$} & \multirow{2}{*}{ 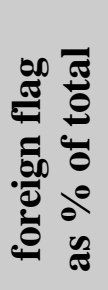 } & & \\
\hline & 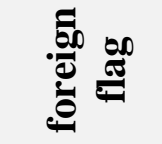 & $\stackrel{5}{\frac{\pi}{2}}$ & & 包 & $\stackrel{5}{\frac{5}{9}}$ & & & \\
\hline Greece & 228383 & 293087 & 77.9 & 243240 & 308837 & 78.8 & 105.4 & 106.5 \\
\hline Japan & 200206 & 228980 & 87.4 & 192270 & 223856 & 85.9 & 97.8 & 96.0 \\
\hline Germany & 107866 & 119181 & 90.5 & 101688 & 112028 & 90.8 & 94.0 & 94.3 \\
\hline China & 84778 & 158884 & 53.4 & 89282 & 165430 & 54.0 & 104.1 & 105.3 \\
\hline $\begin{array}{l}\text { The } \\
\text { Republic } \\
\text { of Korea }\end{array}$ & 62727 & 78834 & 79.6 & 66385 & 80977 & 82.0 & 102.7 & 105.8 \\
\hline $\begin{array}{l}\text { The United } \\
\text { States }\end{array}$ & 52123 & 60279 & 86.5 & 57525 & 67101 & 85.7 & 111.3 & 110.4 \\
\hline Bermuda & 47950 & 48453 & 99.0 & 47545 & 48059 & 98.9 & 99.2 & 99.2 \\
\hline $\begin{array}{l}\text { Taiwan the } \\
\text { Province } \\
\text { of China }\end{array}$ & 41047 & 46141 & 89.0 & 42469 & 46865 & 90.6 & 101.6 & 103.5 \\
\hline $\begin{array}{l}\text { The United } \\
\text { Kingdom }\end{array}$ & 46194 & 51441 & 89.8 & 41202 & 51151 & 80.6 & 99.4 & 89.2 \\
\hline Singapore & 33549 & 95312 & 35.2 & 40743 & 104414 & 39.0 & 109.5 & 121.4 \\
\hline
\end{tabular}


Table 1 (ending)

2016

2017
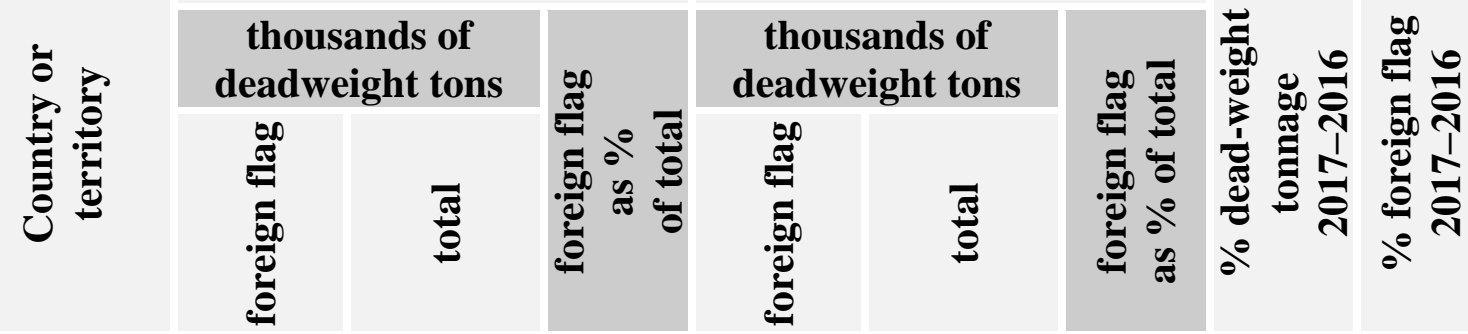

\begin{tabular}{|c|c|c|c|c|c|c|c|c|}
\hline Norway & 30611 & 48188 & 63.5 & 33489 & 51824 & 64.6 & 107.5 & 109.4 \\
\hline Monaco & 29892 & 29892 & 100.0 & 31630 & 31630 & 100.0 & 105.8 & 105.8 \\
\hline $\begin{array}{c}\text { Hong Kong } \\
\text { (China) }\end{array}$ & 19853 & 87375 & 22.7 & 22452 & 93630 & 24.0 & 107.2 & 113.1 \\
\hline
\end{tabular}

\begin{tabular}{|l|l|l|l|l|l|l|l|l|}
\hline Switzerland & 18956 & 20480 & 92.6 & 21931 & 23688 & 92.6 & 115.7 & 115.7 \\
\hline
\end{tabular}

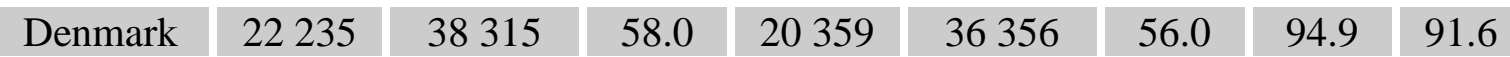

\begin{tabular}{|l|l|l|l|l|l|l|l|l|} 
Turkey & 19639 & 27951 & 70.3 & 19848 & 27733 & 71.6 & 99.2 & 101.1 \\
\hline
\end{tabular}

\begin{tabular}{|l|l|l|l|l|l|l|l|l|}
\hline Belgium & 14575 & 22098 & 66.0 & 15969 & 23550 & 67.8 & 106.6 & 109.6
\end{tabular}

\begin{tabular}{|l|l|l|l|l|l|l|l|l|}
\hline The Russian & 11416 & 18144 & 62.9 & 14857 & 22050 & 67.4 & 121.5 & 130.1 \\
\hline
\end{tabular}

\begin{tabular}{|c|c|c|c|c|c|c|c|c|}
\hline India & 5978 & 21678 & 27.6 & 6199 & 22665 & 27.4 & 104.6 & 103.7 \\
\hline Italy & 7312 & 22739 & 32.2 & 6051 & 20610 & 29.4 & 90.6 & 82.8 \\
\hline
\end{tabular}

Source: calculated by the authors on the basis of data of UNCTAD, Review of Maritime Transport (2017)

Application of various measures of the state protectionism in shipping industry is characterized by certain advantages and shortcomings. Pros and cons of direct protectionist measures should be considered both from the macroeconomic point of view, and from the point of view of shipping companies. From the point of view of ship owners the advantages are: restriction of the competition and simplification of access to cargo base.

Table 2

Top 20 flags of registration with the largest registered fleets

\begin{tabular}{|c|c|c|c|c|c|c|}
\hline \multirow[b]{2}{*}{ Flag } & \multicolumn{2}{|c|}{2016} & \multicolumn{2}{|c|}{2017} & \multirow[b]{2}{*}{ 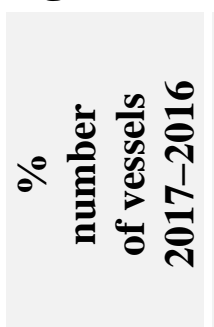 } & \multirow[b]{2}{*}{ 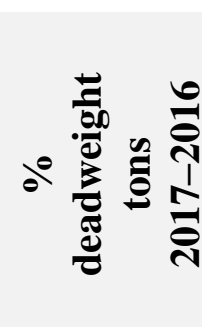 } \\
\hline & 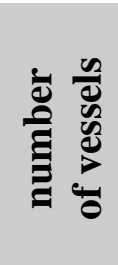 & 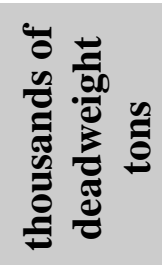 & 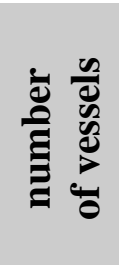 & 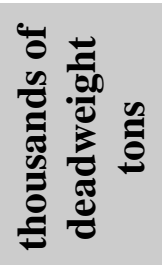 & & \\
\hline Panama & 8153 & 334368 & 8052 & 343398 & 98.8 & 102.7 \\
\hline Liberia & 3185 & 206351 & 3296 & 219397 & 103.5 & 106.3 \\
\hline $\begin{array}{c}\text { The } \\
\text { Marshall } \\
\text { Islands }\end{array}$ & 2942 & 200069 & 3199 & 216616 & 108.7 & 108.3 \\
\hline
\end{tabular}


Table 2 (ending)

\begin{tabular}{|c|c|c|c|c|c|c|}
\hline \multirow[b]{2}{*}{ Flag } & \multicolumn{2}{|c|}{2016} & \multicolumn{2}{|c|}{2017} & \multirow[b]{2}{*}{ 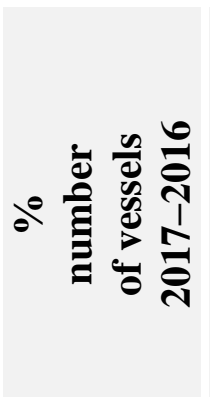 } & \multirow[b]{2}{*}{ 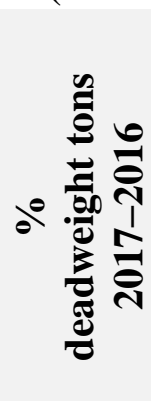 } \\
\hline & 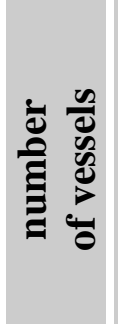 & 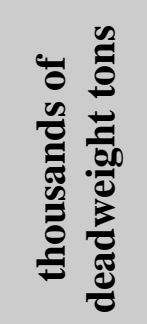 & 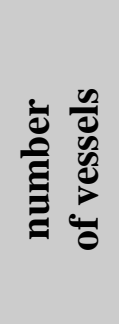 & 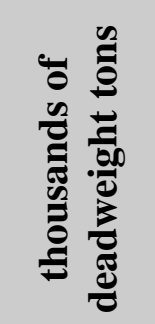 & & \\
\hline $\begin{array}{c}\text { Hong } \\
\text { Kong } \\
\text { (China) }\end{array}$ & 2515 & 161787 & 2576 & 173318 & 102.4 & 107.1 \\
\hline Singapore & 3605 & 127193 & 3558 & 124238 & 98.7 & 97.7 \\
\hline Malta & 2101 & 94992 & 2170 & 99216 & 103.3 & 104.4 \\
\hline Bahamas & 1450 & 79541 & 1440 & 79842 & 99.3 & 100.4 \\
\hline China & 4052 & 75850 & 4287 & 78400 & 105.8 & 103.4 \\
\hline Greece & 1386 & 73568 & 1364 & 74638 & 98.4 & 101.5 \\
\hline $\begin{array}{l}\text { The United } \\
\text { Kingdom }\end{array}$ & 1167 & 37118 & 1551 & 40986 & 132.9 & 110.4 \\
\hline Japan & 5320 & 31869 & 5289 & 34529 & 99.4 & 108.3 \\
\hline Cyprus & 1053 & 33313 & 1022 & 33765 & 97.1 & 101.4 \\
\hline Norway & 1561 & 20697 & 1585 & 21900 & 101.5 & 105.8 \\
\hline Indonesia & 7843 & 18117 & 8782 & 20144 & 112.0 & 111.2 \\
\hline India & 1625 & 16338 & 1674 & 17254 & 103.0 & 105.6 \\
\hline Denmark & 671 & 17185 & 654 & 16893 & 97.5 & 98.3 \\
\hline Italy & 1376 & 16470 & 1430 & 15944 & 103.9 & 96.8 \\
\hline $\begin{array}{l}\text { The } \\
\text { Republic } \\
\text { of Korea }\end{array}$ & 1906 & 16820 & 1907 & 15171 & 100.1 & 90.2 \\
\hline Portugal & 373 & 8878 & 466 & 13753 & 124.9 & 154.9 \\
\hline $\begin{array}{l}\text { The } \\
\text { United } \\
\text { States }\end{array}$ & 3570 & 11841 & 3611 & 11798 & 101.1 & 99.6 \\
\hline
\end{tabular}

Source: calculated by the authors on the basis of data of UNCTAD, Review of Maritime Transport (2017)

From the macroeconomic point of view the benefit is development of national shipping industry, an increase in receipts in the government budget from operation of vessels under national flag and activity of shipbuilding enterprises as well as additional demand for manpower. 
Key financial figures of the global container shipping companies

\begin{tabular}{|c|c|c|c|c|c|c|c|c|c|}
\hline \multirow[b]{2}{*}{ Key figures } & \multicolumn{3}{|c|}{$\begin{array}{l}\text { A.P Moller- } \\
\text { Maersk, million } \\
\text { US dollars / \% }\end{array}$} & \multicolumn{3}{|c|}{$\begin{array}{l}\text { CMA CGM, } \\
\text { million } \\
\text { US dollars / } \% \\
\end{array}$} & \multicolumn{3}{|c|}{$\begin{array}{l}\text { Hapag-Lloyd, } \\
\text { million EUR / } \\
\%\end{array}$} \\
\hline & 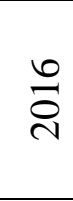 & 홍 & 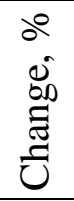 & 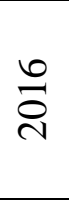 & $\vec{i}$ & 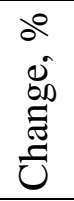 & $\stackrel{0}{\circ}$ & $\stackrel{ }{\vec{i}}$ & 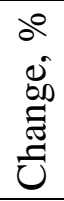 \\
\hline Revenue & 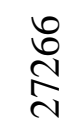 & $\stackrel{n}{8}$ & $\stackrel{m}{=}$ & $\begin{array}{l}\stackrel{8}{2} \\
\stackrel{2}{n}\end{array}$ & 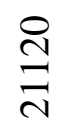 & $\tilde{2}$ & $\stackrel{+}{\stackrel{N}{*}}$ & $\frac{m}{\sigma}$ & సे \\
\hline $\begin{array}{l}\text { Profit before depreciation, } \\
\text { amortization and impairment losses, } \\
\text { etc. (EBITDA) }\end{array}$ & 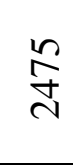 & $\underset{\sim}{\tilde{n}}$ & $\stackrel{m}{ \pm}$ & ते & $\stackrel{n}{n}$ & $\stackrel{m}{n}$ & $\stackrel{+}{\stackrel{0}{0}}$ & $\stackrel{+}{\varrho}$ & $\stackrel{\Xi}{ \pm}$ \\
\hline EBITDA margin, $\%$ & $\vec{a}$ & $\stackrel{+}{=}$ & $\stackrel{\mathscr{2}}{\sim}$ & $\stackrel{\infty}{0}$ & $\stackrel{n}{n}$ & $\stackrel{\dot{g}}{\dot{a}}$ & $\stackrel{2}{\circ}$ & $\begin{array}{l}0 \\
\stackrel{0}{\circ}\end{array}$ & $\stackrel{n}{n}$ \\
\hline Profit / loss & $\stackrel{\hat{\alpha}}{\hat{1}}$ & $\underset{T}{\stackrel{d}{=}}$ & $\begin{array}{l}\dot{a} \\
\dot{a}\end{array}$ & $\sqrt[5]{4}$ & $\overline{2}$ & $\begin{array}{l}\dot{g} \\
\dot{a}\end{array}$ & $\vec{i}$ & $\vec{\sim}$ & $\begin{array}{l}\dot{\Xi} \\
\dot{g}\end{array}$ \\
\hline
\end{tabular}

Source: A.P. Møller - Moersk A/S (2017) Annual report, Copenhagen: Maersk; CMA CGM (2018) Annual Financial Results, Marseille: CMA CGM; Hapag Lloyd (2017) Annual Report, Hamburg: Hapag Lloyd.

Taking into account a difference in the cost of manpower in the developed and developing countries, it is necessary to refer to shortcomings in macroeconomic aspect: growth of transport tariffs due to an increase in capital expenses of ship owners on shipbuilding on shipyards of the countries with the high cost of a manpower and operational costs of the ship owners using national crews. As a result of growth of freight rates, the cost of the goods transported by the sea increases, it negatively affects consumers of these goods. In connection with considerable negative impact of restriction of the competition on cost of the transported goods and development of the coasting fleet, many countries, including the United Kingdom, Australia and China, refused similar direct measures of the state protectionism ${ }^{7}$.

Obvious advantage of application of indirect measures of protectionism in microeconomic aspect is a decrease in tax payments and a possibility of accumulation of money for investment into the new fleet, modernization and renovation. According to the ship owners the advantages of the tonnage tax are the possibility of the decrease in tax expenses; use of the fixed rates that allows to predict a size of tax payments easily; encouragement of development of

7 Primachev N. T., Primachev A. N. (2006) Printsipy integratsii $v$ torgovom sudokhodstve [Principals of integration in trade shipping]. Odessa : Feniks. [in Russian] 
shipping business as the companies using the tonnage tax systems have to operate with vessels; introduction of the tonnage tax contributes to the development of investment activities of shipping companies, allows accumulating money for reproduction of fixed assets.

From the macroeconomic point of view the main advantage consists in a possibility of return of vessels under national flag and the corresponding monetary receipts in the government budget. Negative side of application of indirect measures of the state protectionism in macroeconomic aspect is violation of equal conditions of the competition between shipping companies of the different countries, moving of the fleet belonging to ship owners from the countries, which are not applying similar measures, under the "flags of convenience".

\section{CLASSIFICATION OF METHODS OF THE STATE PROTECTIONISM IN SHIPPING INDUSTRY}

In the publications of the Ukrainian authors, approaches of systematization of the protectionist measures in shipping industry are proposed. In the papers of N. T. Primachev and A. N. Primachev ${ }^{8}$, V. Chekalovets and L. Rozhen ${ }^{9}$ the state entrepreneurship and various methods of legal regulation of shipping are referred to administrative-legal protectionist methods. In the monograph by O. M. Kotlubai ${ }^{10}$ administrative and credit-financial protectionist methods in shipping are allocated.

A number of publications are devoted to certain protectionist methods in shipping industry. In the article by W. Murray ${ }^{11}$ modern aspects of use of the Merchant Marine Act of 1920, known as the Jones Act, regulating U.S. domestic transportation, are considered. In the paper of I. A. Rusinov,

8 Chekalovets V., Rozhen L. (1999) Predprinimatel'skaya deyatel'nost' v sfere morskikh torgovykh perevozok (Rol' gosudarstva) [Entrepreneurial activity in the sphere of maritime transport (Role of State)]. Business-Inform, no. 17-18, pp. 52-59.

9 Kotlubai O. M. (2004) Ekonomichni mekhanizmy rozvytku torhovelnoho moreplavannia v Ukraini [Economical mechanisms of development of trade shipping in Ukraine]. Odessa : Institute of market problems and economical and ecological research. [in Ukrainian]

10 Murray W. (2017) End Protectionism in the Shipping Industry. Real Clear Policy (electronic journal), July 22, 2017. URL: https://www.realclearpolicy.com/ articles/2017/07/22/end_protectionism_in_the_shipping_industry.html (accessed November 2, 2018).

11 Rusinov I. A., Gavrilova I. A., Nelogov, A. G. (2016) Vopros regulirovaniya lineynogo sudokhodstva na osnove analiza polozheniy Konventsii OON o Kodekse povedeniya lineynykh konferentsiy [Question of liner shipping regulation on the base of United Nations Convention on a Code of Conduct for Liner Conferences]. Bulletin of the Admiral Makarov State University of marine and inland shipping, no. 3(37), pp. 53-64. [in Russian] 
I. A. Gavrilova and A. G. Nelogov ${ }^{12}$ the purposes and the principles of the United Nations Convention on a Code of Conduct for Liner Conferences are considered.

In the article by M. Kalouptsidi ${ }^{13}$ models of governmental subsidizing of world shipbuilding industry allowing a decrease in shipbuilding expenses are developed. In the paper of D. Pupavac, L. Krpan and R. Marsanic ${ }^{14}$ it is shown that subsidies in maritime transport make sense only on the condition of improvement of the quality of transport services.

To direct methods of the state protectionism in shipping industry it is necessary to carry the measures, which are directly limiting the competition in the market of sea transport services. The leader in use of direct measures of protectionism in shipping is the United States. There are bilateral agreements with the countries exporting commodities to the United States according to which these transportations have to be made by vessels under the U.S. flag. Transportation within military orders and government programs are legislatively reserved to the U.S. fleet, the percentage of cargo is required to be carried on U.S. - flag vessels is: $100 \%$ for military cargo (governed by Military Cargo Preference Act of 1904); $100 \%$ for Export Import Bank (governed by Public Resolution 17); at least $50 \%$ for Civilian Agencies cargo and $50 \%$ for agricultural cargoes (governed by Cargo Preference Act of $1954)^{15}$. Despite the decrease in application of cargo reservation in the world in recent years, cargo preferences were applied in some countries of Africa, Asia and Latin America.

The UNCTAD Code of Conduct for Liner Conferences ${ }^{16}$ defining shares of national carriers is an example of the multilateral agreement between the countries. The principle enshrined in the Code (principle 40:40:20) comes down to the fact that the group of national shipping lines of each of two countries has the equal rights for participation in transportation on a freight and quantity of the cargoes relating to their mutual foreign trade and which are carried out by a Conference. Shipping lines of the third countries, which participate in a Conference, can receive $20 \%$ of the transportation concerning this trade on a freight and quantity of cargo.

${ }^{12}$ Kalouptsidi M. (2017) Detection and Impact of Industrial Subsidies: The Case of Chinese Shipbuilding. Cambridge: Department of Economics, Harvard University.

${ }^{13}$ Pupavac D., Krpan L., Marsanic R. (2017) The Effect of Subsidies on the Offer of Sea Transport. Our sea, no. 64(2), pp. 54-57.

14 Maritime Administration (MARAD) (1954) Cargo Preference Act of 1954, Washington: MARAD.

15 Admiralty and Maritime Law Guide (1974) Convention on a Code of Conduct for Liner Conferences, Geneva: Admiralty and Maritime law guide.

16 U.S. Senate Commerce Committee (1920) The Merchant Marine Act of 1920, Washington: Commerce Committee. 
In the majority of countries domestic transportation are legislatively assigned to the fleet under national flag within public policy of protectionism that limits the competition from foreign carriers and gives national shipping companies guaranteed cargo base. A classic example is the Jones $\mathrm{Act}^{17}$ adopted in the United States in 1920. The law establishes that shipping of cargo between the U.S. ports should be carried out by the vessels built in the United States, at least for $75 \%$ belonging to U.S. citizens, operating under the U.S. flag with the crew of the U.S. citizens. In recent years the monopoly position of the American carriers leads to the increase of capital and operational costs of ship owners, growth of transport tariffs and consumer expenses, causes damage to economy of the United States, has negative effect on economies of Alaska, Hawaii and Puerto Rico ${ }^{18}$.

The Russian Federation since 2018 imposed a ban on transportation by vessels under foreign flags across the Northern Sea Route of oil, natural gas, gas condensate and coal extracted in the territory of the Russian Federation and in the territory which is under its jurisdiction ${ }^{19}$. Icebreaking and pilot vessels, the coastal fleet and vessels for shelf resource researches also have to be under the Russian flag. The purpose is the receipt in the budget of the Russian Federation of revenues from transportation of the Russian cargo. Also, Russian shipbuilding enterprises can receive benefit from these measures.

One more example is the restriction of export of liquid palm oil and coal by the vessels controlled by the Indonesian carriers, entered in 2018 by the Ministry of Trade of the Republic of Indonesia ${ }^{20}$.

Thus, the direct methods of protectionism, applied today in the shipping industry, include: bilateral and multilateral agreements in the sphere of shipping between the countries; cargo reservation on transportation of domestic cargo for vessels under national flags; cargo reservation on transportation within state programs (strategic cargo, military cargo, food and others) to the national fleet.

${ }^{17}$ Grennes T. (2017) An Economic Analysis of the Jones Act. Washington: Mercatus Center of George Mason University.

18 State Duma of Russian Federation (1999) Kodeks torgovogo moreplavaniya Rossiyskoy Federatsii [Merchant Shipping Code Of The Russian Federation]. Moscow: State Duma of Russian Federation.

19 The Maritime Executive (2018) Protectionism makes a comeback in international shipping. The Maritime Executive (electronic journal), February 14, 2018. URL: https://www.maritime-executive.com/article/protectionism-makes-a-comeback-ininternational-shipping\#gs.5o8_E_8 (accessed November 1, 2019).

${ }^{20}$ Tax Consultants International (2017) The Dutch tax regime and incentives for shipping companies. Tax Consultants International (electronic journal), January 19, 2017. URL: https://www.tax-consultants-international.com/read/The_Dutch_tonnage_tax_regime (accessed November 1, 2019). 
Despite application of direct measures of protectionism in the certain countries, taking into account the high level of competition in the market of sea transport services and requirements of the GATT, the WTO and The Organization for Co-operation and Development (OECD), under the conditions of trade and shipping liberalization, time of direct measures of the state protectionism passed. Efforts of the majority of developed countries are directed to the increase of the competitiveness of the national transport. Adjustment policy of the EU shipping is based on openness of the global markets, equal access for all participants to the market of sea transport services, at the same time the EU countries do not refuse indirect methods of protectionism concerning shipping industry.

The international ship registers in the majority of the countries provide the ship owners with different types of the tax benefits including the alternative system of taxation - the tonnage tax regime. Application of the tonnage tax in developed countries since the 1990s is connected with outflow of the fleet under "flags of convenience". The tonnage tax regimes are applied in Greece, the Netherlands. Germany, Belgium, Denmark, Italy, France, Norway, the United Kingdom, Finland, Poland, China, Japan, India and others countries including a number of offshore jurisdictions. The schemes of the tonnage tax have different forms in various countries.

Results of the comparative analysis of Dutch tonnage tax regime and Norwegian Special Tax System for the Shipping are represented in tab. 4. The Dutch tonnage tax regime is the most widespread tonnage tax scheme. On this model a taxation subject is not the real profit of shipping company, but the settlement size of profit that will be defined by multiplication of the net tonnage of vessels of the company by the standard size of daily profit per ton established by the legislation ${ }^{21}$. Such settlement profit for one or several vessels is assessed on the established corporate tax rate. The Dutch regime can be used for the vessels operating in the international transportation, dredging and other kinds of activity and can be applied for ten years. At the same time the shipping company has to be registered in the Netherlands. There is no requirement about registration of vessels under the Netherlands flag, but vessels have to be registered under the flag of the EU Member State. The method of the accelerated tax depreciation and reduction of wage tax cannot be applied under the condition of the choice of the tonnage tax regime.

The Norwegian Special Tax System for Shipping assumes calculation of a tax on the basis of a uniform rate depending on the NT of vessels ${ }^{22}$.

${ }^{21}$ Ministry of Trade, Industries and Fisheries (Norway) (2017) The Norwegian Special Tax System for Shipping 2018-2027. Oslo: Ministry of Trade, Industries and Fisheries.

${ }^{22}$ The Norwegian Tax Administration (2018) Depreciation rates in Norway. Oslo: The Norwegian Tax Administration. 


\section{Comparing Dutch and Norwegian tonnage tax schemes}

\begin{tabular}{|c|c|c|c|}
\hline \multicolumn{2}{|c|}{ Dutch tonnage tax regime } & \multicolumn{2}{|c|}{ Norwegian Special Tax System for Shipping } \\
\hline \multicolumn{4}{|c|}{ Rates of fixed profit } \\
\hline $\begin{array}{l}\text { Net tonnage (NT) } \\
\text { of ship }\end{array}$ & $\begin{array}{l}\text { Fixed profit per } \\
1000 \text { NT per day }\end{array}$ & Net tonnage of ship & $\begin{array}{l}\text { Fixed profit per } \\
1000 \text { NT per day }\end{array}$ \\
\hline $0-1000 \mathrm{NT}$ & $€ 9.08$ & $0-1000 \mathrm{NT}$ & NOK 0.9 per $100 \mathrm{NT}$ \\
\hline up to $10000 \mathrm{NT}$ & $€ 6.81$ & for the first $1000 \mathrm{NT}$ & NOK 9 per $1000 \mathrm{NT}$ \\
\hline up to $2000 \mathrm{NT}$ & $€ 4.54$ & from 1001 to $10000 \mathrm{NT}$ & OK 18 per $1000 \mathrm{NT}$ \\
\hline up to $50000 \mathrm{NT}$ & $€ 2.27$ & from 10001 to $25000 \mathrm{NT}$ & NOK 12 per $1000 \mathrm{NT}$ \\
\hline $50000 \mathrm{NT}$ or more & & above $25000 \mathrm{NT}$ & NOK 6 per $1000 \mathrm{NT}$ \\
\hline \multicolumn{4}{|c|}{ Kinds of activity } \\
\hline \multicolumn{2}{|c|}{$\begin{array}{l}\text { Operating of vessels including } \\
\text { commercial and technical management } \\
\text { used in international transportation of } \\
\text { cargo and passengers, for dredging, } \\
\text { research activity and others. }\end{array}$} & \multicolumn{2}{|c|}{$\begin{array}{l}\text { Operating of transport ships owned or chartered } \\
\text { (passenger and cargo ships, cable laying vessels and } \\
\text { others), support vessels in petroleum activities, } \\
\text { ancillary activities are closely connected to the } \\
\text { transport activities (loading, unloading and storage } \\
\text { of goods, leasing out of containers, sale of goods and } \\
\text { services for consumption on board and others). }\end{array}$} \\
\hline \multicolumn{4}{|c|}{ Duration of application of the taxation scheme } \\
\hline \multicolumn{2}{|c|}{$\begin{array}{l}10 \text { years, then it is possible to continue to } \\
\text { use the tonnage tax or to return to the } \\
\text { usual corporate tax system. It can be } \\
\text { cancelled earlier. }\end{array}$} & \multicolumn{2}{|c|}{$\begin{array}{l}1 \text { year or more (from } 1 \text { January } 2018 \text { until } 31 \\
\text { December 2027). }\end{array}$} \\
\hline \multicolumn{4}{|c|}{ Method of calculation } \\
\hline \multicolumn{2}{|c|}{$\begin{array}{l}\text { The tonnage tax is based on NT and } \\
\text { determined by five size groups. }\end{array}$} & \multicolumn{2}{|c|}{$\begin{array}{l}\text { The tonnage tax is based on NT and determined by } \\
\text { four size groups. In the } 0 \text { to } 1000 \mathrm{NT} \text { interval, the } \\
\text { tonnage will be rounded to the nearest } 100 \mathrm{NT} \text {. } \\
\text { Tonnage exceeding } 1000 \mathrm{NT} \text { will be rounded to the } \\
\text { nearest thousand NT. }\end{array}$} \\
\hline \multicolumn{4}{|c|}{ Flag } \\
\hline \multicolumn{2}{|c|}{$\begin{array}{l}\text { Ship should be registered in one of EU } \\
\text { Member State (exceptions are available } \\
\text { for ships under the "third flag" that will } \\
\text { join an existing fleet). }\end{array}$} & \multicolumn{2}{|c|}{$\begin{array}{l}\text { The ship should be registered in one of the European } \\
\text { Economic Area (EEA) Member States. }\end{array}$} \\
\hline \multicolumn{4}{|c|}{ Legal features } \\
\hline \multicolumn{2}{|c|}{$\begin{array}{l}\text { A shipping company must carry out } \\
\text { commercial and technical ship } \\
\text { management in the Netherlands of a } \\
\text { vessel which it owns and co-owns, } \\
\text { excepting of ships chartered out on } \\
\text { bareboat charter or holds under bareboat } \\
\text { charter. }\end{array}$} & \multicolumn{2}{|c|}{$\begin{array}{l}\text { A company must own either a ship or shares or } \\
\text { interests in limited liability companies, partnerships or } \\
\text { controlled foreign corporations that own ships. A } \\
\text { company can perform full management. Vessels may } \\
\text { be operated under voyage charter, time charter or } \\
\text { bareboat charter. }\end{array}$} \\
\hline
\end{tabular}

Source: produced by the authors

The tonnage tax may be reduced by up to $25 \%$ based on the environmental rating of the vessel. The tonnage tax scheme can be applied by private and public limited companies carrying out shipping activities. Vessels can also be 
held through domestic or foreign partnership and controlled by foreign corporations based in low tax countries, a company have to own a vessel or shares or interests in companies, partnerships or controlled by a foreign corporation that own such a ship. In the Norwegian system there are no entry and exit barriers, unlike the Dutch tonnage tax regime.

One of the most widespread methods of indirect protectionism is the accelerated tax depreciation for vessels. The accelerated tax depreciation provides write-off of the most part of a vessel value in the first years of operation. The value of fixed capital being subject to depreciation can be equal to the sum of initial expenses or is reduced by the sum that can be received on delivery of the vessel on demolition. For example, the Netherlands shipping companies at the choice of the corporate tax can use the accelerated tax depreciation with the maximum annual rate of $20 \%$ of the estimated residual value of the vessel. However, if a profit is not enough for a depreciation sum covering, then the part that was not utilized can be carried forward to the subsequent year. In Norway the rate of depreciation of $14 \%$ a year of book value is applied to the vessels ${ }^{23}$.

In tab. 5 the different types of tax incentives used in activity of shipping companies in different countries are generalized.

Methods of credit and financial regulation also include subsidizing of ship owners and shipbuilders and preferential crediting. Different types of subsidies to shipping industry were provided in China, South Korea, Taiwan and other countries in recent years ${ }^{24}$. Chinese ship owners received subsidies on scrap of Chinese-flagged vessels at Chinese demolition shipyards and ship building on Chinese shipyards.

The shipbuilding subsidies to shipping companies and the subsidies directed to stimulation of vessels demolition are the most widespread.

An example of preferential crediting is the Norwegian new financing scheme for building of vessels for coastal shipping, which was entered in 2018. The scheme assumes granting export credits to shipping companies and shipbuilding enterprises under guarantees of the Norwegian Guarantee Institute for Export Credits (GIEC), the value of the guarantee is limited in NOK 10 billion $^{25}$.

In fig. 1 the classification of indirect methods of credit and financial regulation in shipping industry is presented. The classification is specified by allocation of various types of tax incentives, subsidizing and preferential crediting.

${ }^{23}$ Soren Skou (2018) Calls for an End to Subsidies. The Maritime Executive. (electronic journal), April 27, 2018. URL: https://www.maritime-executive.com/article/soeren-skoucalls-for-an-end-to-subsidies (accessed November 4, 2019).

25 Export credit Norway (2018) New Norwegian ship financing scheme launched. Export credit Norway (electronic journal), June 28, 2018. URL: https://www.eksportkreditt.no/en/ 2018/06/28/new-norwegian-ship-financing-schemelaunched/ (accessed November 7, 2019). 
Tax incentives in activity of shipping companies

\begin{tabular}{|c|c|c|c|c|}
\hline Country & $\begin{array}{l}\text { Corporate } \\
\text { tax }\end{array}$ & Tonnage tax & $\begin{array}{c}\text { Additional tax } \\
\text { concessions }\end{array}$ & $\begin{array}{c}\text { Tax } \\
\text { depreciation }\end{array}$ \\
\hline 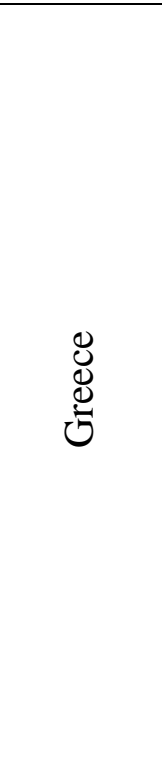 & $\begin{array}{l}\text { Shipping } \\
\text { enterprises } \\
\text { don't use } \\
\text { corporate } \\
\text { tax. }\end{array}$ & $\begin{array}{l}\text { Tonnage tax is } \\
\text { defined taking into } \\
\text { account gross } \\
\text { tonnage and age of } \\
\text { vehicle. It is used to } \\
\text { Greek-flagged } \\
\text { vessels and other } \\
\text { vehicles in operating } \\
\text { the domestic } \\
\text { companies. }\end{array}$ & $\begin{array}{l}\text { Cargo and } \\
\text { passenger vehicles } \\
\text { which operating } \\
\text { between Greek and } \\
\text { foreign seaports, or } \\
\text { between foreign } \\
\text { seaports, have } 50 \% \\
\text { additional discount } \\
\text { from tonnage tax. } \\
\text { Ships built in } \\
\text { Greece and } \\
\text { registered in Greek } \\
\text { Vessel Registry } \\
\text { have tonnage tax } \\
\text { exemption during } \\
\text { first } 6 \text { years. }\end{array}$ & n. m. \\
\hline 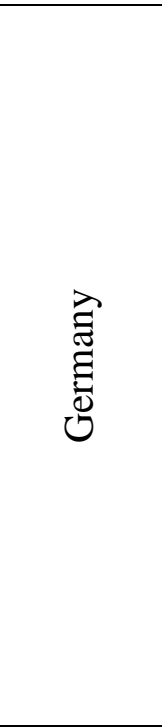 & $\begin{array}{l}\text { Base rate of } \\
15 \% \text { (total } \\
\text { up to } 33 \% \\
\text { including } \\
\text { trade tax } \\
\text { and } \\
\text { solidarity } \\
\text { tax). }\end{array}$ & $\begin{array}{l}\text { Taxable profit is } \\
\text { determined by } 4 \text { size } \\
\text { groups, it is applied } \\
\text { at operation of trade } \\
\text { vessels on interna- } \\
\text { tional cargo and } \\
\text { passenger transport- } \\
\text { tation, to German } \\
\text { ship managers, to } \\
\text { vessels registered in } \\
\text { German Shipping } \\
\text { Register and the } \\
\text { vessels under other } \\
\text { flags operated from } \\
\text { German territory. }\end{array}$ & $\begin{array}{l}95 \% \text { of a capital } \\
\text { gain from the sale } \\
\text { of shares in a } \\
\text { foreign subsidiary } \\
\text { or domestic } \\
\text { company is exempt } \\
\text { from tax when } \\
\text { received by a } \\
\text { company taxable in } \\
\text { Germany. }\end{array}$ & $\begin{array}{l}\text { Straight line } \\
\text { method for } \\
\text { ships (useful } \\
\text { life for tax } \\
\text { depends on } \\
\text { specific of } \\
\text { vehicle). } \\
\text { The declining- } \\
\text { balance } \\
\text { method is not } \\
\text { used. }\end{array}$ \\
\hline 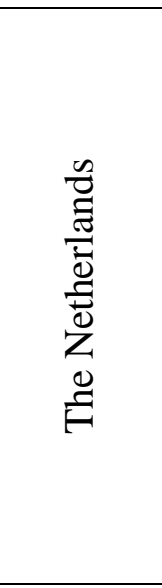 & $\begin{array}{l}20-25 \% \\
\text { depending } \\
\text { on profit } \\
\text { value. }\end{array}$ & $\begin{array}{l}\text { Fixed profit is } \\
\text { determined by } 5 \text { size } \\
\text { groups. Vessels can } \\
\text { be operated under } \\
\text { any EU flag. It can } \\
\text { be applied only to } \\
\text { operating vehicles in } \\
\text { international } \\
\text { transportation, } \\
\text { including ship } \\
\text { management } \\
\text { companies. }\end{array}$ & $\begin{array}{l}\text { Corporate tax } \\
\text { exemption for } \\
\text { foreign shipping } \\
\text { companies (gains } \\
\text { from the operations } \\
\text { of ships in } \\
\text { international traffic } \\
\text { to and from the } \\
\text { Netherlands). VAT } \\
\text { exemptions for } \\
\text { shipping within EU. }\end{array}$ & $\begin{array}{l}\text { Accelerated } \\
\text { method for a } \\
\text { corporate } \\
\text { income tax } \\
\text { purpose. } \\
\text { Maximum } \\
20 \% \text { a year. }\end{array}$ \\
\hline
\end{tabular}


Table 5 (continuance)

\begin{tabular}{|c|c|c|c|c|}
\hline Country & $\begin{array}{l}\text { Corporate } \\
\quad \operatorname{tax}\end{array}$ & Tonnage tax & $\begin{array}{l}\text { Additional tax } \\
\text { concessions }\end{array}$ & $\begin{array}{c}\text { Tax } \\
\text { depreciation }\end{array}$ \\
\hline 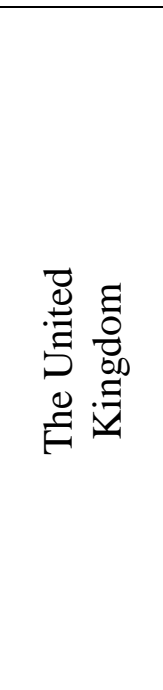 & $\begin{array}{l}\text { Base rate of } \\
19 \% \text {. }\end{array}$ & $\begin{array}{l}\text { Fixed profit is } \\
\text { determined by } 4 \text { size } \\
\text { groups. Commercial } \\
\text { or strategic } \\
\text { management has to } \\
\text { be carried out in the } \\
\text { UK. There is no } \\
\text { specific requirement } \\
\text { for vessels in the } \\
\text { regime to be the UK } \\
\text { or the EU flagged. } \\
\text { The company has to } \\
\text { use the system at } \\
\text { least } 10 \text { years. }\end{array}$ & $\begin{array}{l}\text { There are capital } \\
\text { allowances, which } \\
\text { are the expense } \\
\text { deductions (as } \\
\text { alternative of } \\
\text { amortization). }\end{array}$ & $\begin{array}{l}\text { Amortization is } \\
\text { not deducted } \\
\text { when } \\
\text { calculating the } \\
\text { corporate tax. }\end{array}$ \\
\hline $\begin{array}{l}\stackrel{\vec{E}}{\Xi} \\
\dot{\Xi}\end{array}$ & $\begin{array}{l}\text { Corporate } \\
\text { tax }\end{array}$ & Tonnage tax & $\begin{array}{l}\text { Additional tax } \\
\text { concessions }\end{array}$ & $\begin{array}{l}\text { Tax } \\
\text { depreciation }\end{array}$ \\
\hline 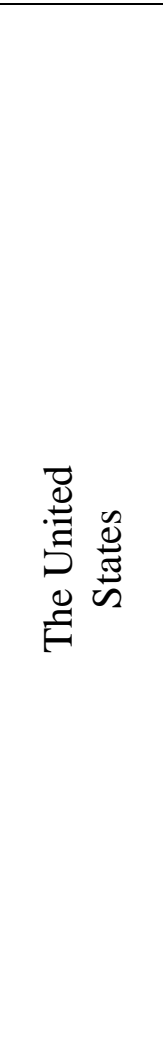 & $21 \%$ & $\begin{array}{l}\text { The US does not } \\
\text { charge } \\
\text { special tonnage tax o } \\
\mathrm{n} \text { the ships of a } \\
\text { particular foreign } \\
\text { country if that } \\
\text { country does not } \\
\text { charge such } \\
\text { special tonnage tax o } \\
\mathrm{n} \text { the U.S. flag ships. }\end{array}$ & $\begin{array}{l}\text { Assistance } \\
\text { programs providing } \\
\text { tax deferral } \\
\text { benefits to U.S.- } \\
\text { flag operators } \\
\text { (The Construction } \\
\text { Reserve Fund) and } \\
\text { deferment of } \\
\text { income taxes } \\
\text { (The Capital } \\
\text { Construction } \\
\text { Fund). From } 2018 \\
100 \% \text { first-year } \\
\text { bonus depreciation } \\
\text { deduction is } \\
\text { allowed for certain } \\
\text { qualified property } \\
\text { acquired and } \\
\text { placed in service } \\
\text { after } 27.09 .2017 \\
\text { and before } \\
1.01 .2023 \text {. }\end{array}$ & $\begin{array}{l}\text { Declining- } \\
\text { balance } \\
\text { (e.g., } 200 \% \\
\text { double- } \\
\text { declining- } \\
\text { balance } \\
\text { method) or } \\
\text { straight-line } \\
\text { methods. }\end{array}$ \\
\hline
\end{tabular}


Table 5 (ending)

\begin{tabular}{|c|c|c|c|c|}
\hline Country & $\begin{array}{l}\text { Corporate } \\
\text { tax }\end{array}$ & Tonnage tax & $\begin{array}{l}\text { Additional tax } \\
\text { concessions }\end{array}$ & $\begin{array}{c}\text { Tax } \\
\text { depreciation }\end{array}$ \\
\hline 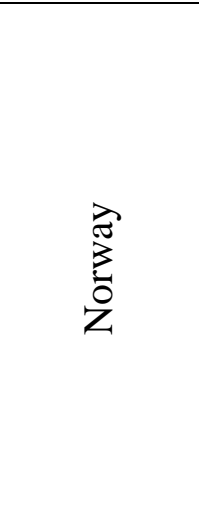 & $\begin{array}{l}\text { For the } \\
\text { resident } \\
\text { companies } \\
\text { of Norway } \\
\text { the usual } \\
\text { rate of } \\
23 \% \text {. }\end{array}$ & $\begin{array}{l}\text { Taxable profit is } \\
\text { determined by } 4 \text { size } \\
\text { groups. The system } \\
\text { is applied to ship } \\
\text { owners, charterers } \\
\text { and to various } \\
\text { activities connected } \\
\text { with transport. Ships } \\
\text { should be operated } \\
\text { under the flag of } \\
\text { EEA country. }\end{array}$ & $\begin{array}{l}\text { Tax exemption for } \\
\text { capital gains. }\end{array}$ & $\begin{array}{l}\text { The declining- } \\
\text { balance } \\
\text { method: } \\
14 \% \text { for ships, } \\
\text { vessels, } \\
\text { offshore rigs, } \\
\text { etc. }\end{array}$ \\
\hline Japan & $\begin{array}{l}\text { Base rate of } \\
23.4 \% \text {. }\end{array}$ & $\begin{array}{l}\text { Tonnage tax was } \\
\text { applied for some } \\
\text { large Japanese } \\
\text { oceangoing shipping } \\
\text { companies during } \\
5 \text { years (since } 2009 \text { ). }\end{array}$ & $\begin{array}{l}\text { The special } \\
\text { depreciation } \\
\text { scheme for } \\
\text { environmentally } \\
\text { friendly ships. }\end{array}$ & $\begin{array}{l}\text { Straight line } \\
\text { method: from } \\
25 \% \text { to } 7.7 \% \text {; } \\
\text { declining- } \\
\text { balance } \\
\text { method: from } \\
50 \% \text { to } 15.4 \% \text {. } \\
\text { Useful life: } \\
\text { 4-13 years. }\end{array}$ \\
\hline $\begin{array}{l}\text { The } \\
\text { Russian } \\
\text { Federation }\end{array}$ & $20 \%$ & $\begin{array}{l}\text { At registration in the } \\
\text { Russian International } \\
\text { Register of Vessels } \\
\text { the state fee at initial } \\
\text { registration and } \\
\text { annual payment are } \\
\text { paid. }\end{array}$ & $\begin{array}{l}\text { From } 1.01 .2019 \\
\text { operating expenses } \\
\text { of the vessels } \\
\text { registered in the } \\
\text { Russian } \\
\text { International } \\
\text { Register of Vessels } \\
\text { and income from } \\
\text { operation and } \\
\text { realization of the } \\
\text { vessels built by the } \\
\text { Russian } \\
\text { shipbuilders after } \\
1.01 .2010 \text { won't be } \\
\text { considered for a } \\
\text { taxable basis. }\end{array}$ & $\begin{array}{l}\text { Based on the } \\
\text { useful life of } \\
\text { vessels, } \\
\text { amortization } \\
\text { may be } \\
\text { calculated } \\
\text { using either the } \\
\text { reducing- } \\
\text { balance method } \\
\text { or straight line } \\
\text { method. }\end{array}$ \\
\hline
\end{tabular}

Source: drew up by the authors 


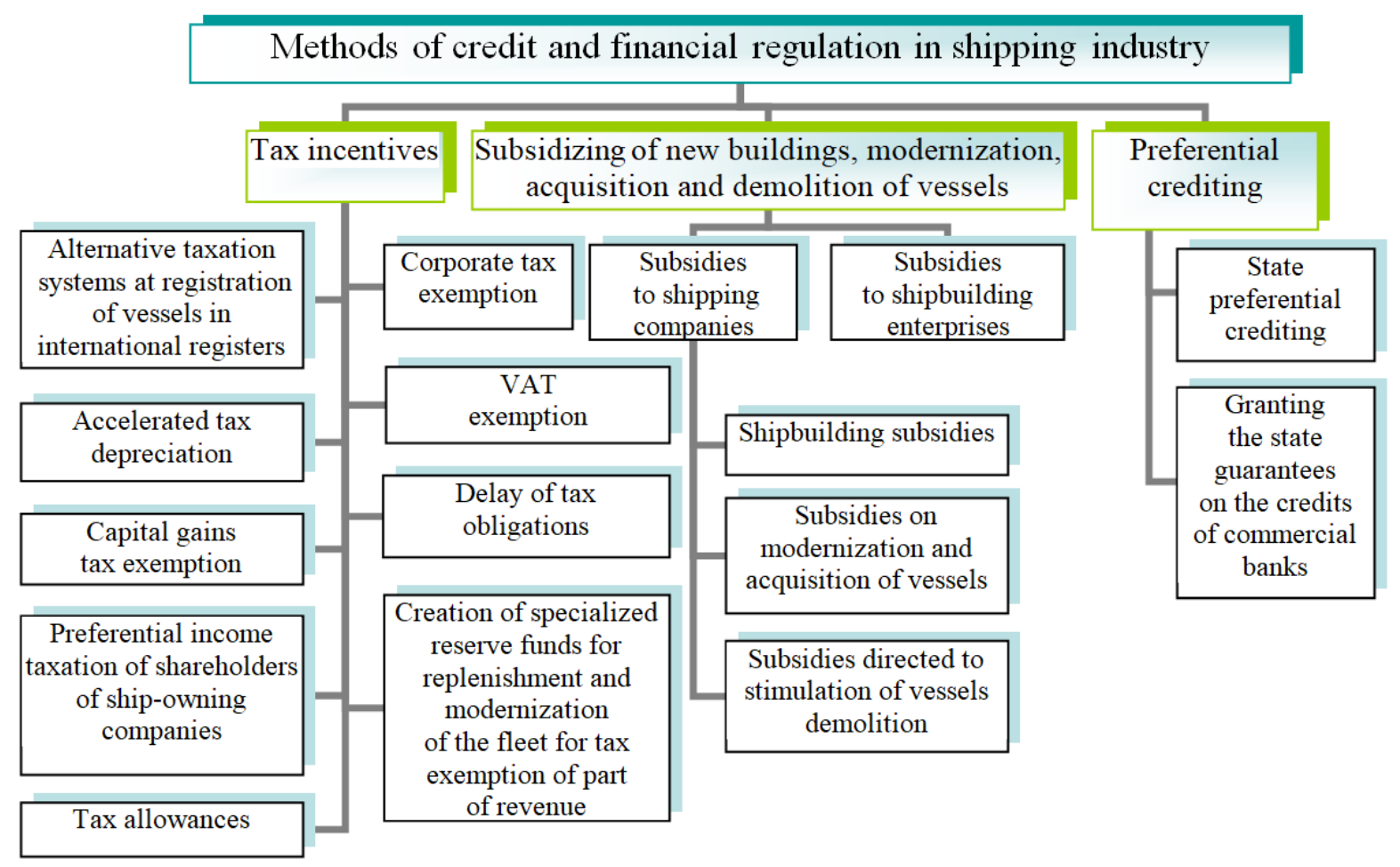

Fig. 1. Classification of methods of credit and financial regulation in shipping industry Source: produced by the authors

\section{CONCLUSIONS}

Application of protectionist measures in shipping industry is caused by low profitability of business, high level of competition and volatility on the international freight markets, the continuing outflow of vessels in offshore jurisdictions and the aspiration of governments to develop national fleets, to ensure economic security.

The classification of protectionist measures in shipping industry is improved by specification of the structure of indirect methods. The scientific representation about state protectionism in shipping industry gained further development by systematization of practical experience of application of direct and indirect measures in shipping and allocation of the main trends of protectionism: prevalence of indirect measures of protectionism over direct methods in connection with the policy of trade and shipping liberalization in the majority of developed countries of the world; expansion in recent years the practice of such direct measures of protectionism as cargo reservation on transportation of domestic and export-import cargo for vessels under national flags and fixing to the national fleet of the cargo transported within state programs; dissemination in developed countries of the tonnage tax regimes and other alternative taxation systems at registration of vessels in international ship registers for fight against outflow of national fleets in offshore jurisdictions; application in a number of developed countries of tax incentives for shipping companies, at the same time in the majority of the countries the specified tax 
concessions are applied at the choice of payment of the corporate tax by ship owners and do not work for the tonnage tax regime; application of various types of state subsidizing and preferential crediting for stimulation of national fleet development.

The advantages of protective measures according to the ship owners are: simplification of access to cargo, possibility of maximizing revenue, reductions of tax expenses, capital costs and growth of investments into renewal of the fleet. Among the disadvantages of protectionist measures it is necessary to highlight a growth of transport tariffs due to an increase in capital and operational costs of ship owners, an increase in cost of the goods transported by sea connected with direct competition restrictions, uneven development of shipping industry in the different countries.

\section{SUMMARY}

In the article the practical experience of the state protectionism in shipping industry at the current stage of its development is systematized. The reasons of protectionism on maritime transport are considered; the analysis of the world fleet ownership and flags of registration is conducted. The comparative analysis of the Dutch and Norwegian tonnage tax regimes and other current tax incentives in the different countries is made. The advantages and shortcomings of protectionist measures in shipping industry from the macroeconomic and microeconomic points of view are analysed. The scientific representation of state protectionism in shipping industry gained further development by systematization of international experience of application of direct and indirect measures in shipping and allocation of the main trends of protectionism. The classification of protectionist measures in shipping industry is improved by specification of the structure of indirect methods.

The main advantages of protective measures according to the ship owners are: simplification of access to cargo, possibility of maximizing revenue, reductions of tax expenses, capital costs and growth of investments into renewal of the fleet. Among the main disadvantages of protectionist measures it is necessary to highlight a growth of transport tariffs due to an increase in capital and operational costs of ship owners, an increase in cost of the goods transported by sea connected with direct competition restrictions, uneven development of shipping industry in different countries.

\section{REFERENCES}

1. United Nations Conference of trade and development (2017) Review of Maritime Transport, Geneva: UNCTAD.

2. Odeke A. (1984) Protectionism and the Future of International Shipping. Dordrecht: Martinus Nijhoff Publishers. 
3. Yannopoulos G. N. (1989) World Shipping: Between Liberalism and Protectionism. North Carolina Journal of International Low and Commercial Regulation, vol. 14, no. 1, pp. 45-53.

4. Parameswaran B. (2004) The liberalization of Maritime Transport Services. Berlin: Springer-Verlag Berlin and Heidelberg GmbH \& Co. KG.

5. Kirk A. (2017) Protectionism is on the rise as US and EU implement thousands of restrictive trade measures. The Telegraph (electronic journal), November 28, 2017. URL: https://www.telegraph.co.uk/business/2017/11/28/ mapped-protectionism-rise-us-eu-implement-thousands-restrictive/ (accessed November 2, 2018).

6. European Community Shipowners' Association (2017) Shipping and global trade. Toward to EU external shipping policy, Brussels: ECSA.

7. Zhykharieva V., Shyriaieva L., Vlasenko O. (2019) Current trends of protectionism in shipping industry. Transport Problems, vol. 14, issue 2, pp. 89-100. DOI 10.20858/tp.2019.14.2.8

8. Primachev N. T., Primachev A. N. (2006) Printsipy integratsii v torgovom sudokhodstve [Principals of integration in trade shipping]. Odessa: Feniks. [in Russian]

9. Chekalovets V., Rozhen L. (1999) Predprinimatel'skaya deyatel'nost' $\mathrm{v}$ sfere morskikh torgovykh perevozok (Rol' gosudarstva) [Entrepreneurial activity in the sphere of maritime transport (Role of State)]. Business-Inform, no. $17-18$, pp. 52-59.

10. Kotlubai O. M. (2004) Ekonomichni mekhanizmy rozvytku torhovelnoho moreplavannia $\mathrm{v}$ Ukraini [Economical mechanisms of development of trade shipping in Ukraine]. Odessa: Institute of market problems and economical and ecological research. [in Ukrainian]

11. Murray W. (2017) End Protectionism in the Shipping Industry. Real Clear Policy (electronic journal), July 22, 2017. URL: https://www.realclearpolicy.com/articles/2017/07/22/end_protectionism_in_th e_shipping_industry.html (accessed November 2, 2018).

12. Rusinov I. A., Gavrilova I. A., Nelogov, A. G. (2016) Vopros regulirovaniya lineynogo sudokhodstva na osnove analiza polozheniy Konventsii OON o Kodekse povedeniya lineynykh konferentsiy [Question of liner shipping regulation on the base of United Nations Convention on a Code of Conduct for Liner Conferences]. Bulletin of the Admiral Makarov State University of marine and inland shipping, no. 3(37), pp. 53-64. [in Russian]

13. Kalouptsidi M. (2017) Detection and Impact of Industrial Subsidies: The Case of Chinese Shipbuilding. Cambridge: Department of Economics, Harvard University.

14. Pupavac D., Krpan L., Marsanic R. (2017) The Effect of Subsidies on the Offer of Sea Transport. Our sea, no. 64 (2), pp. 54-57. 
15. Maritime Administration (MARAD) (1954) Cargo Preference Act of 1954, Washington: MARAD.

16. Admiralty and Maritime Law Guide (1974) Convention on a Code of Conduct for Liner Conferences, Geneva: Admiralty and Maritime law guide.

17. U.S. Senate Commerce Committee (1920) The Merchant Marine Act of 1920, Washington: Commerce Committee.

18. Grennes T. (2017) An Economic Analysis of the Jones Act. Washington: Mercatus Center of George Mason University.

19. State Duma of Russian Federation (1999) Kodeks torgovogo moreplavaniya Rossiyskoy Federatsii [Merchant Shipping Code Of The Russian Federation]. Moscow: State Duma of Russian Federation.

20. The Maritime Executive (2018) Protectionism makes a comeback in international shipping. The Maritime Executive (electronic journal), February 14, 2018. URL: https://www.maritime-executive.com/article/protec tionism-makes-a-comeback-in-international-shipping\#gs.5o8_E_8 (accessed November 1, 2019).

21. Tax Consultants International (2017) The Dutch tax regime and incentives for shipping companies. Tax Consultants International (electronic journal), January 19, 2017. URL: https://www.tax-consultants-international.com/read/The_Dutch_tonnage_tax_regime (accessed November 1, 2019).

22. Ministry of Trade, Industries and Fisheries (Norway) (2017) The Norwegian Special Tax System for Shipping 2018-2027. Oslo: Ministry of Trade, Industries and Fisheries.

23. The Norwegian Tax Administration (2018) Depreciation rates in Norway. Oslo: The Norwegian Tax Administration.

24. Soren Skou (2018) Calls for an End to Subsidies. The Maritime Executive. (electronic journal), April 27, 2018. URL: https://www.maritime-executive.com/article/soeren-skou-calls-for-an-end-tosubsidies (accessed November 4, 2019).

25. Export credit Norway (2018) New Norwegian ship financing scheme launched. Export credit Norway (electronic journal), June 28, 2018. URL: https://www.eksportkreditt.no/en/2018/06/28/new-norwegian-ship-financingscheme-launched/ (accessed November 7, 2019).

Information about the authors: Zhykharieva V. V., Prof, Dr. in Economics, Head of Economics and Finance Department, Odessa National Maritime University 34, Mechnikov str., Odessa, 65000, Ukraine ORCID ID: orcid.org/0000-0002-2179-8483 
Shyriaieva L. V., Prof, Dr. in Economics, Prof. of Economics and Finance Department, Odessa National Maritime University 34, Mechnikov str., Odessa, 65000, Ukraine ORCID ID: orcid.org/0000-0002-4706-2167

Vlasenko O. S., $\mathrm{PhD}$ in Economics, Associate Prof. of Economics and Finance Department, Odessa National Maritime University 34, Mechnikov str., Odessa, 65000, Ukraine ORCID ID: orcid.org/0000-0001-9669-4438 